\title{
The International Politics of Ireland's EU/IMF Bailout
}

\author{
Michael Breen \\ Centre for International Studies, School of Law and Government, Dublin City University
}

\begin{abstract}
In 2010, Ireland's financial crisis threatened the stability of the global financial system, precipitating an international rescue package of 85 billion euro. This article analyses the bailout from an international relations perspective in order to gain a deeper insight into the nature of the political pressures that forced the negotiators to compromise over the design and content of Ireland's programme of financial support. It does so by drawing on recent academic research on the politics of IMF decision-making. The lessons from this literature can help to shed light on one of the most important events in post-Independence Ireland.
\end{abstract}

\section{INTRODUCTION}

In 2010, Ireland's financial crisis threatened the stability of the global financial system, precipitating an international rescue package of 85 billion euro. ${ }^{1}$ To fight the scale of the losses in the banking system and the immediacy of the European sovereign debt crisis, the government consented to a long-term adjustment programme under the IMF's extended fund facility. The terms of the programme - the conditionality-demand years of cutbacks in public spending to contain the government's exploding deficit, as well as measures to breathe new life into the banking system. The broader contours of the programme, described in Ireland's 'Letter of Intent' to the IMF, European Central Bank (ECB), and European Commission (EC), aim at nothing less than a complete transformation of Ireland's economy and society, away from a construction-led boom to an export-driven, global platform for foreign investment.

Unfortunately, from its inception the programme lacked credibility, both domestically and internationally, because it was unable to place Ireland on a sustainable debt path without further European support. Almost two years later, a bitter debate continues over the terms of the programme. In particular, the absence of a 'haircut' for the unguaranteed senior bondholders of Irish banks remains one of the most contentious issues in Irish politics. One can only conclude that the architects of Ireland's programme were forced to compromise: to 'buy time' in anticipation of further European support for Ireland's unsustainable debt dynamics. This article analyses the bailout from the perspective of international relations in order to gain a deeper insight into the nature of the political pressures that forced the negotiators to compromise. It does so by drawing on the latest academic literature on the politics of IMF decision-making, which finds that countries receive different treatment during

Author's e-mail: Michael.breen@dcu.ie

doi: 10.3318/ISIA.2012.23.??

${ }^{1}$ As a consequence, Ireland is only the third rich country, after Iceland and Greece, to participate in an IMF programme since the United Kingdom in 1976. 
bailout negotiations for a range of political and economic reasons. The lessons from this literature can help to shed light on one of the most important events in post-Independence Ireland.

The article is structured as follows. First, I review the growing literature on how powerful states can influence IMF bailout negotiations. The 'lion's share' of these studies highlights the commanding role of the United States in IMF policy, with a minority considering the influence of the other shareholders and private actors in the world economy. I then discuss the role of the chief negotiators-the IMF's staff. This literature argues that the IMF is mostly comprised of responsible technocrats but that there is sometimes potential for rent-seeking. An alternative perspective argues that the IMF bureaucracy's unique organisational culture can manipulate both powerful states and technocrats to influence negotiations.

In the second part of the article, I examine the events surrounding Ireland's 2010 EU/IMF programme. After first providing the background to the financial crisis, the discussion considers how the different perspectives from the IMF literature can shed light on Ireland's negotiations with the Troika. I find stronger support for explanations that focus on the economic and financial interests of the IMF's large shareholders. There is less convincing evidence to support some of the other explanations, namely those that focus on geopolitics, the preferences of the IMF's bureaucracy, and domestic politics in the bailout recipient.

\section{THE INTERNATIONAL POLITICS OF IMF DECISION-MAKING}

Ireland's programme of financial support was designed by officials from the IMF, EU and Ireland but it is a typical long-term IMF programme in many respects. It is comprised of IMF policy conditions - structural benchmarks and performance criteria- that have been applied in hundreds of other countries. Ireland's progress in implementing the policy conditions is continually monitored by the IMF's staff and the organisation's shareholders. ${ }^{2}$ At the most general level, there are two broad approaches to explaining how politics affects the negotiation, design, and content of these kinds of programmes. The first approach emphasises the external drivers of IMF policy, most notably the influence of the powerful states that have a controlling interest in the organisation. The second approach stresses the internal drivers, specifically the IMF's bureaucracy. Within each of these broad approaches there are many variations. For example, among scholars who focus on the Fund's bureaucracy, some view it as a benign technocracy, while others argue that the integrity of its programmes has been undermined by staff rent-seeking.

The IMF's main decision-making forum is its executive board, which meets daily to discuss its programmes and policies. It is comprised of five directors appointed by the United States, United Kingdom, France, Germany and Japan (hereafter the G5). The remaining 19 seats on the 24-member council are filled by election. Without having to contest elections, the representatives of the large shareholders do not need to cater to the interests of other countries in advance of elections, allowing their representatives to advance their own countries' national interests more effectively. Apart from this advantage, the G5 possess around 40 per cent of the IMF's votes, giving them the ability to easily form a coalition to pass any decision over lending, conditionality or programme design. Even without the need to form a coalition, the G5 have enough votes to veto any major policy decision that would change the way in which the organisation is governed by its membership, thus preserving the status quo. As such, the group's power is enshrined in the organisation's rules and design. However, it is rarely invoked or formally exercised. Instead, it prefers informal decision-

\footnotetext{
${ }^{2}$ For a discussion of surveillance relevant to Ireland see Michael Breen, 'IMF surveillance of Ireland during the Celtic Tiger', Irish Political Studies 27 (3) (2012), 431-9.
} 
making procedures, leading to the appearance of consensus. That the organisation proceeds by consensus gives the other member states an incentive to participate, as long as they do not form coalitions to block programmes that are favourable to G5 interests.

\section{The United States}

Scholars of international relations have long argued that the US has a privileged and commanding position at the IMF. ${ }^{3}$ Its influence has been a source of great controversy, with many arguing that it is substantial and above that of any other member-state. ${ }^{4}$ Anecdotal evidence of US interventions abounds. Charles Calomiris, for example, commenting on an IMF loan to Ecuador, noted that it was viewed by many as a side payment to the Ecuadoran government in return for the continuing use of military bases to monitor drug traffic. ${ }^{5}$ Similarly, Calomiris speculated that Pakistan's access to an IMF loan may have been conditional on its willingness to sign a nuclear non-proliferation treaty. Going beyond mere anecdotes, systematic qualitative research has already illustrated the importance of the United States in selected lending cases; according to Bessma Momani, the United States intervened in 1987 and 1991 to secure lenient IMF treatment for Egypt in order to preserve the political stability of the pro-Western Egyptian regime during that period. ${ }^{6}$

Are these once-off interventions or does the US regularly use and abuse the IMF? In the first quantitative study of US influence at the IMF, Strom Thacker examined the relationship between voting patterns at the United Nations and the probability that a country would receive a loan from the IMF and found that countries which moved towards the US position on key issues were more likely to get a loan. Similarly, countries that move away from the US are less likely to do so. ${ }^{7}$ Since Thacker's study, several other studies have confirmed his original findings ${ }^{8}$ although others have found no evidence of a link. ${ }^{9}$

Besides this participation in IMF programmes, researchers have found evidence of US influence over conditionality. Axel Dreher and Nathan Jensen, for example, find that closer allies of the US-again measured by voting affinity in the UN-have to meet fewer

\footnotetext{
${ }^{3}$ Stephen D. Krasner, 'The International Monetary Fund and the third world', International Organization 22 (3) (1968), 670-88.

${ }^{4}$ C. Randall Henning, 'US interests and the International Monetary Fund', Peter G. Peterson Institute for International Economics Policy Brief 09-12 (2009); Miles Kahler, 'The United States and the International Monetary Fund: declining influence or declining interest?', in Margaret P. Karns and Karen A. Mingst (eds), The United States and multilateral institutions: patterns of changing instrumentality and influence (Boston, 1990); Ngaire Woods, 'The United States and the international financial institutions: power and influence within the World Bank and the IMF', in Rosemary Foot, S. Neil MacFarlane and Michael Mastanduno (eds), US hegemony and international organizations (Oxford, 2003); Ngaire Woods and Domenico Lombardi, 'Uneven patterns of governance: how developing countries are represented in the IMF', Review of International Political Economy 13 (3) (2006), 480-515.

${ }^{5}$ Charles W. Calomiris, 'When will economics guide IMF and World Bank reforms?' Cato Journal 20 (1) (2000), 85-103.

${ }^{6}$ Bessma Momani, 'American politicization of the International Monetary Fund', Review of International Political Economy 11 (5) (2004), 880-904.

${ }^{7}$ Strom C. Thacker, 'The high politics of IMF lending', World Politics 52 (1) (1999), 38-75.

8 Thomas Barnebeck Andersen, Thomas Harr and Finn Tarp, 'On US politics and IMF lending', European Economic Review 50 (2006), 1843-62; Robert J. Barro and Jong-Wha Lee, 'IMF programs: who is chosen and what are the effects?', Journal of Monetary Economics 52 (2005), 1245-69; Grigore Pop-Eleches, From economic crisis to reform: IMF programs in Latin America and Eastern Europe (Princeton, 2008).

${ }^{9}$ Barry Eichengreen, Poonam Gupta and Ashoka Mody, 'Sudden stops and IMF-supported programs', IMF Working Paper WP/06/101 (2006).
} 
conditions. $^{10}$. Similarly, Randall Stone finds that the US does intervene strategically to reduce the scope of conditionality for favoured borrowing countries. ${ }^{11}$

Another important policy decision concerns when to re-admit a country to an IMF programme following its failure to implement the conditions of its previous programme. In two separate studies on Africa and Eastern Europe, Stone found that countries with strategic links to the US, the UK and France received shorter programme suspensions or "punishment intervals', before being allowed to continue to draw on Fund resources. ${ }^{12}$ Thomas Oatley and Jason Yackee also argue that US interests decisively shape IMF short-term lending programmes. In a study of the period from 1986-1998, the authors find that the size of IMF loans is dependent on the extent of US banking and foreign policy interests in the borrowing countries. ${ }^{13}$ Similarly, J. Lawrence Broz and Michael Hawes find evidence that US commercial bank exposure increases the likelihood of IMF assistance for a country experiencing a financial crisis. ${ }^{14}$ Finally, in a study of conditionality agreements from 19902002, Stone has found even more evidence of US influence in reducing the severity of conditionality in strategically important countries. ${ }^{15}$

These studies provide an impressive array of evidence on the importance of US interests across several prominent IMF policies (lending, conditionality, programme approval, punishment intervals). There are also a number of implications for Ireland's 2010 EU/IMF programme. First, one would expect the US to support any IMF-led rescue programme for Ireland even if the loan far exceeded the IMF's normal financing limitations. The immediate threat to the US financial system would most likely allow the US Department of the Treasury to overcome any opposition to the bailout from Congress. Second, given the demonstrated ability of the US to influence IMF policy, it would most likely intervene in negotiations between Ireland and the IMF/EC/ECB if any of the programme's content ran contrary to US interests. Previous research has demonstrated that US support for major bailouts is rarely unconditional in cases of high geopolitical or financial importance. US involvement could take many forms including intervention to secure financing or to reduce the severity of conditionality.

\section{The large shareholders}

While there is an impressive array of evidence on the role of the US, there are not as many studies that consider the other powerful shareholders-Germany, France, the United Kingdom and Japan. This is a puzzling omission because there is not that much of a gap in IMF voting power between these shareholders and the United States. There is also, at the same time, a commonly held view among leading international economists and policy-makers that the Fund's largest shareholders have substantial input into the IMF's broader goals and mission. $^{16}$

${ }^{10}$ Axel Dreher and Nathan M. Jensen, 'Independent actor or agent? An empirical analysis of the impact of US interests on IMF conditions', The Journal of Law and Economics 50 (1) (2007), 105-24.

${ }^{11}$ Randall W. Stone, 'The scope of IMF conditionality', International Organization 62 (2008), 589620.

${ }^{12}$ Randall Stone, Lending credibility: the International Monetary Fund and the post-Communist transition (Princeton, 2002); Randall Stone, 'The political economy of IMF lending in Africa', American Political Science Review 98 (4) (2004), 577-91.

${ }^{13}$ Thomas Oatley and Jason Yackee, 'American interests and IMF lending', International Politics 41 (2004), 415-29.

${ }^{14}$ J. Lawrence Broz and Michael Brewster Hawes, 'Congressional Politics of Financing the International Monetary Fund', International Organization 60(1) (2006), 367-99.

${ }^{15}$ Stone, 'The scope of IMF conditionality'.

${ }^{16}$ James M. Boughton, Silent revolution: the International Monetary Fund, 1979-1989 (Washington, DC, 2001); Michele Fratianni and John Pattison, 'Who is running the IMF: Critical shareholders or the staff?', 
One notable exception that explores the role of other shareholders is Stone's analysis of IMF lending in Africa, which finds that both British and French influence exists over the duration of 'punishment intervals' or length of time during which a country is punished for failing to fulfil the terms of its programme before finally being allowed to continue to draw on Fund resources. ${ }^{17}$ Seonjou Kang goes further, arguing that the Fund's five largest shareholders-the G5-intervene to relax conditionality where their strategic and financial interests are at stake. ${ }^{18}$ Dreher and Jensen's study also establishes a statistical relationship between G7 voting at the United Nations General Assembly and IMF conditionality in regard to borrowing countries. ${ }^{19}$

Mark Copelovitch argues that conditionality decisions are dependent on the heterogeneity and intensity of G5 interests in each specific case that comes before the Executive Board but finds limited evidence to support this argument from a statistical analysis of conditionality. ${ }^{20}$ Michael Breen, on the other hand, finds that the large shareholders engage in a co-operative bargaining process such that IMF agreements contain fewer binding conditions when a suspension of IMF lending plausibly would impose greater hardship on creditor country banks and exporters. ${ }^{21}$

What all of these studies suggest is that the US is not the only important stakeholder during financial crises. Other powerful states also have an important role in international negotiations. This is particularly relevant to Ireland, Greece, and Portugal, where the IMF's large European shareholders-Germany, France, and the United Kingdom-had a much greater stake in the outcome of bailout negotiations than the United States. As for the US, an emerging literature predicts that the other large shareholders should support any IMF-led rescue programme for Ireland even if the loan far exceeded the IMF's normal financing limitations. Given the immediate threat to the global financial system, and the economic interdependence of the world's largest economies, they would be able to overcome any domestic opposition.

While it is likely that the powerful shareholders could intervene in negotiations between Ireland and the IMF if any of the programme's content ran contrary to their interests, it is less clear how they co-operate as a group to influence negotiations. Breen argues that the G5 shareholders tend to support the most exposed shareholder. So for example, the US should support the German and French position in international negotiations with the Irish government. $^{22}$ Therefore, if any features of Ireland's programme were to run contrary to the Germany or French interests, intervention should be expected. Copelovitch's argument leaves more room for conflict among the US and the European shareholders over Ireland's programme, opening up the possibility that the IMF's staff can sometimes have a much stronger role in international negotiations, ${ }^{23}$ whereas Stone suggests that the European

Indiana University, Kelley School of Business, Department of Business, Economics and Public Policy Working Paper 2004-06 (2004); Lex Rieffel, Restructuring sovereign debt: the case for ad hoc machinery (Washington, DC, 2003); Nouriel Roubini and Brad Setser, Bailouts or bail-ins? responding to financial crises in emerging economies (Washington, DC, 2004).

${ }^{17}$ Stone, 'The political economy of IMF Lending in Africa'.

${ }^{18}$ Seonjou Kang, 'Agree to reform? The political economy of conditionality variation in International Monetary Fund lending, 1983-1997', European Journal of Political Research 46 (5) (2007), 685-720.

${ }^{19}$ Dreher and Jensen, 'Independent actor or agent? An empirical analysis of the impact of US interests on IMF conditions'.

${ }^{20}$ Mark S. Copelovitch, 'Master or servant? Common agency and the political economy of IMF lending', International Studies Quarterly 54 (1) (2010), 49-77.

${ }^{21}$ Michael Breen, 'IMF conditionality and the economic exposure of its shareholders', European Journal of International Relations (forthcoming 2013).

${ }_{22}^{2}$ Michael Breen, 'IMF conditionality and the economic exposure of its shareholders'.

${ }^{23}$ Mark S. Copelovitch, 'Master or servant? Common agency and the political economy of IMF lending'. 
shareholders should have little influence during negotiations. ${ }^{24}$ While the literature is somewhat divided on how the world's most powerful economies co-operate during negotiations with countries like Ireland, political economists are united behind the argument that powerful states have influence over IMF programmes.

\section{The borrowers}

So far I have focused on the powerful shareholders; however, an alternative view is that politics in the potential recipients of IMF financing are decisive during negotiations. Policy makers in Ireland should, according to this view, seize the opportunity to introduce groundbreaking reforms in key areas like health, education or social welfare, where the government has previously been unable to make progress. According to Vreeland, this is a common feature of IMF arrangements, which are often designed to provide political cover for governments that would otherwise be unable to implement any necessary adjustment. ${ }^{25}$ Another view is that IMF programmes are ultimately the outcome of negotiation between the IMF staff and officials from the borrowing country, suggesting that the partisan interests of the politicians and parties drive government policy, and therefore need to be considered when trying to explain variation in IMF behaviour. ${ }^{26}$ However, many countries have few other options but to turn to the IMF for assistance following an economic shock and cannot afford the luxury of picking and choosing among financiers. This leaves borrowing countries in a weak position to refuse IMF assistance. Rather, it seems more plausible that IMF programmes are designed to respond to borrowing countries' economic needs, rather than their demands. ${ }^{27}$ Nevertheless, politicians and officials from the borrowing country have input into programme design and are ultimately responsible for implementation.

\section{The bureaucracy}

For many years international relations (IR) theorists had little to say about how international bureaucracies affect world politics. For the most part, bureaucracies were treated as entities with no independence from their creators. In recent times, scholars have argued that we need to turn our attention to understanding how international organisations actually work, what they do after they are created and whether their behaviour conforms to expectations. ${ }^{28}$ As a result, there are now several studies of the IMF that stress the internal logic of its behaviour. The first approach, originating mainly from economics, views the Fund as a benign technocracy that tries but often fails to provide global public goods. Many economists have long viewed the IMF as a technocracy, where experts use their control over decision-making to design and implement optimal policies. Sometimes referred to as the 'optimal policy

\footnotetext{
${ }^{24}$ Stone, Controlling institutions: international organizations and the global economy (Cambridge, 2011).

${ }^{25}$ James R. Vreeland, 'Why do governments and the IMF enter into agreements? Statistically selected cases', International Political Science Review 24 (3) (2003), 321-43.

${ }^{26}$ Pop-Eleches, From economic crisis to reform: IMF programs in Latin America and Eastern Europe, 5.

${ }^{27}$ Another novel argument is that private financiers drive variation in IMF policies. According to this view, private financiers hold a key advantage over the IMF: they have the ability to supplement IMF loans and can threaten to withdraw supplementary financing if the terms of an IMF programme are not to their liking. See Erica R. Gould, 'Money talks: supplementary financiers and International Monetary Fund's Conditionality', International Organization 57 (3) (2003), 551-86; Erica R. Gould, Money talks: the International Monetary Fund, conditionality and supplementary financiers (Chicago, 2006), 19.

${ }^{28}$ Michael N. Barnett and Martha Finnemore, 'The politics, power and pathologies of International Organizations', International Organization 53 (4) (1999), 699-732; Michael N. Barnett and Martha Finnemore, Rules for the world: international organizations in global politics (Ithaca, NY, 2004).
} 
approach', this view of the IMF's behaviour rests on several assumptions. ${ }^{29}$ First, it assumes that the Fund is largely free from political interference and that it uses this freedom to provide global public goods. Second, the approach assumes that the staff and political representatives who design and oversee the organisation's policies are mostly interested in translating the latest insights from economic theory into good policies which in turn lead to good outcomes like economic growth. Whenever the Fund fails to deliver optimal policies, so the story goes, this is due to market failures or a lack of information. When applied to Ireland's bailout negotiations, supporters of this approach would argue that the key features of the rescue programme - the pace of the fiscal adjustment, the size of the loan and the issue of debt restructuring-would be based only on sound economic policy and that the Irish government, its shareholders and European institutions would generally follow the IMF's advice even in cases where it runs contrary to their interests.

Another approach, also first articulated among economists, contends that bureaucrats, particularly of the international variety, have incentives towards rent-seeking behaviour. ${ }^{30}$ Coming broadly under the label of public choice, supporters of this approach expect principal-agent relationships to determine the behaviour and activities of the IMF. According to Roland Vaubel, in years where the Fund's budget is reviewed by the Board of Governors (quota review years), the staff should 'hurry-up lending' ${ }^{31}$ By depleting resources in the year of a quota review, the bureaucracy is sending a strong signal to the shareholders that its current budget allocation is stretched to capacity and should be increased. This sort of behaviour is standard practice in bureaucracies with budget cycles; both spending and lending should increase at the end of the cycle. Supporters of this view would argue that the IMF is sometimes too 'trigger happy': in order to increase its own revenue it is willing to lend to countries like Ireland while also relaxing the strictness of conditionality to encourage borrowing. 32

\section{SEPTEMBER 2008 AND IRELAND'S 2010 EU/IMF PROGRAMME}

When Greece secured financial support in 2010 the focus of international markets and the IMF turned immediately to Ireland, which was engulfed in the worst financial crisis it had experienced since the foundation of the state. ${ }^{33}$ In September 2008, the government had taken the unorthodox step of issuing a two-year blanket guarantee of the liabilities of Irishcontrolled banks. The blanket guarantee stands outs as unnecessarily ambitious in scope

${ }^{29}$ Thomas Willett, 'Towards a broader public choice analysis of the IMF', in David Andrews, C.

Randall Henning and Louis Pauly (eds), Organizing the world's money: a festschrift in honor of Benjamin J. Cohen (Ithaca, NY, 2002).

${ }^{30}$ Bruno S. Frey, 'The public choice of international organizations', in Dennis Mueller (ed.), Perspectives on public choice (Cambridge, 1997); Bruno S. Frey, 'The public choice view of international political economy', International Organization 38 (1) (1984), 199-223; Roland Vaubel and Thomas D. Willett (eds), The political economy of international organizations: a public choice perspective (Boulder, Colorado, 1991).

${ }^{31}$ Roland Vaubel, 'Bureaucracy at the IMF and the World Bank: a comparison of the evidence', World Economy 19 (2) (1996), 195-210; Roland Vaubel, 'The moral hazard of IMF lending', World Economy 6 (3) (1983), 291-303; Roland Vaubel, 'The political economy of the International Monetary Fund: a public choice analysis'.

${ }^{32}$ An alternative view-the organisational culture approach-rejects the notion that bureaucracies are driven only by agents acting according to their interests and preferences. This approach turns its attention, rather, to the IMF's organisational culture, stressing the importance of norms, shared beliefs and socialisation processes. One of its implications is that bureaucracies, particularly the IMF's, can take on a life of their own, becoming uncontrollable in some respects. See Barnett and Finnemore, 'The politics, power and pathologies of international organizations'.

${ }^{33}$ This is the first occasion in which Ireland has participated in an IMF programme although it had come perilously close to requesting IMF support in the $1980 \mathrm{~s}$. 
when compared with other measures used to contain systemic financial crises. ${ }^{34}$ Nevertheless, it initially had a positive effect on market behavior: deposits returned to Irish banks, sparking outrage among some officials in other governments. Despite its initial success it soon became clear that the losses in Irish banks were much worse than anticipated and that the government could not possibly meet the terms of its own guarantee without bankrupting its own citizens. From that point forward, Ireland required external assistance if it was to avoid a messy sovereign default.

Preliminary discussions among the ECB, EC, the IMF and officials in the Irish administration proceeded over the summer months about the possibility of financial support. ${ }^{35}$ By late summer of 2010 the government still had access to international funding but Ireland's position began to deteriorate sharply at the end of September. As the news about Ireland's banks became worse, it became clear that markets would not rollover previous loans. This was compounded by ECB council members who spooked depositors by signaling the institution's reluctance to maintain open-ended support for the Irish banking system. During September, depositors withdrew 18 billion euro from domestic banks and 13 billion euro from non-domestic banks. Overall, deposits had declined by roughly 125 billion euro from a peak of 600 billion euro in late $2008 .{ }^{36}$ As the bank run accelerated, the ECB's commitment to support the banking system was no longer enough to contain the crisis: a programme of financial support was necessary to draw a line under the loss of confidence in the government's guarantee of the banking system's liabilities.

Although the Irish authorities' discussions with the IMF had been ongoing, the administration was reluctant to acknowledge their existence. In early October 2010, the minister for finance, Brian Lenihan, travelled to Washington D.C. to meet with the IMF. This marked a crucial turning point for the Irish administration-by the end of the meeting there was a general view that some form of external help would be required. The spread-or difference between the price of Irish and German government bonds-had reached such high levels that by 4 November, the governor of the central bank, Patrick Honohan, had formed the view that Ireland had passed a critical threshold-a point of no return-and that discussions with the IMF should commence over the possibility of financial assistance. Honohan subsequently informed Kevin Cardiff at the Department of Finance that this critical threshold of sustainability had been exceeded. ${ }^{37}$ While senior officials in the Irish administration were now aware of the necessity of IMF support, this view was not necessarily shared by senior politicians. Key members of the government, namely the minister for finance, Brian Lenihan, were still holding out for an arrangement without IMF involvement. Presumably acting with the consent of the taoiseach, the Department of Finance adopted a strategy of denial in the hope that the ECB/EC would provide a package of financial support that would allow the administration to 'save face' domestically. ${ }^{38}$

The government most likely wanted a flexible line of credit rather than a traditional IMF stand-by or extended programme, so that it would not have to endure the humiliation of

${ }^{34}$ For a discussion of these methods see Patrick Honohan and Luc Laeven, Systemic financial crises: containment and resolution (Cambridge, 2003). For a discussion of the blanket guarantee see Patrick Honohan, 'Resolving Ireland's banking crisis', The Economic and Social Review 40 (2) (2009), 207-31.

${ }^{35}$ AJ Chopra, Director of the European Department, International Monetary Fund, RTÉ Prime Time Special, 28 November 2011.

${ }^{36}$ Gary O'Callaghan, 'Did the ECB cause a run on Irish Banks? Evidence from disaggregated data', Irish Economy Note No. 13 (February 2011). Available online at: www.irisheconomy.ie/Notes/IrishEconomyNote13.pdf (accessed 20 August 2012).

${ }^{37}$ Patrick Honohan, Governor of the Central Bank of Ireland, RTÉ Prime Time Special, 28 November

2011.

${ }^{38}$ The Irish government first denied rumours regarding IMF support on 17 September and later on 15 November. 
signing a formal IMF agreement and could go on to frame the promise of financial support as merely a precautionary measure. However, the ECB Governing Council and members of the Eurogroup of Finance Ministers had resolved to take action, regardless of the delaying tactics or preferences of the Irish administration. It is alleged that just two days before a deal was agreed, a letter was sent from the president of the ECB, Jean-Claude Trichet, to the minister for finance, Brian Lenihan, threatening the withdrawal of emergency liquidity assistance if Ireland did not accept a bailout. ${ }^{39}$ In the end, it was the governor of the central bank, Patrick Honohan, who took the unprecedented step of bypassing the government and making a public announcement on morning radio that financial assistance was imminent.

\section{The role of the shareholders}

Although Ireland's EU/IMF programme is only one of hundreds of similar bailouts over the last few decades, it ranks as one of the largest in history. Collectively, the world's largest economies had no choice but to orchestrate a series of bilateral and multilateral loans towards the bailout. The crisis was of such a magnitude that Ireland was the first item on the agenda of the G20 summit, the fifth meeting of the G20 heads of government, which took place in South Korea in mid-November $2011 .^{40}$ Officials from the US Treasury feared possible contagion from the crisis in Ireland and made it clear they were prepared to intervene if necessary. ${ }^{41}$ The IMF literature has demonstrated that the world's most powerful economies do not support unconditional bailouts - the terms of such bailouts rarely go against their strategic and economic interests.

As negotiations continued over the form of financial support Ireland would receive, a clear division emerged between the European shareholders and the IMF's staff. The minister for finance, Brian Lenihan, had discussed the possibility of imposing losses on the senior bondholders of Irish banks with the IMF's managing director, Dominque Strauss-Kahn, and the president of the ECB, Jean-Claude Trichet. During the negotiations, the IMF mission team, led by AJ Chopra, the deputy director of the European department, was in agreement with the Irish authorities that some form of haircut should be imposed on the senior bondholders of Irish banks who were not covered by the extensive government guarantee. This position was shot down by the European Central Bank and the other large IMF shareholders. ${ }^{42}$ They made it clear that they would not support a programme unless Ireland agreed to cover the losses of all senior bondholders, even those not covered by the Irish government's guarantee. In all likelihood, the key shareholders-France and Germanyfeared that a comprehensive debt restructuring deal for Irish banks would expose the weaknesses in their banks, which were highly exposed to Ireland and the rest of the European periphery. A further consequence of granting Ireland better terms would be the necessity to revisit Greece's deal and to possibly hasten negotiations with other failing economies. And furthermore, for their generosity, the French and German governments feared they might suffer a worse electoral backlash for being seen to use taxpayers' funds to help the European periphery.

For the most part, the main shareholders adopted a unified position during the negotiations. The ECB/EC and the French and German governments were united in their preference that even unguaranteed senior bondholders would not have to suffer losses. While

\footnotetext{
${ }^{39}$ David Raleigh, 'Michael Noonan: I'm willing to overrule finance officials and release ECB letter on bailout', Irish Independent, 27 August 2012.

${ }^{40}$ Eamon Ryan, Minister for Communications, Energy and Natural Resources, RTÉ Prime Time Special, 28 November 2011.

${ }^{41}$ RTÉ Prime Time Special on the Bailout, 28 November 2011.

${ }^{42}$ The details of these events were first made public by Morgan Kelly in his article 'Ireland's future depends on breaking free from bailout', Irish Times, 5 May 2011.
} 
the other IMF shareholders could have blocked the deal they eventually supported the European position. At a conference call with the G7 finance ministers, the US secretary of the Treasury, Timothy Geithner, was of the view that bank bondholders should not shoulder losses. Geithner also intervened in the 1997 Asian financial crisis when he was an official in the US Treasury. During crisis negotiations he met with the IMF's mission and persuaded them to support Thailand to guarantee deposits in its bust banks, helping to settle a bitter dispute among the IMF's staff over this issue. ${ }^{43}$ When details of Geithner's intervention in the Irish case were leaked to the media, an unnamed senior US government official responded that: 'The ECB and EC were both dead opposed and they are decisive. The US is not a decision-maker on European issues' ${ }^{44}$

Although the full extent of the role of the shareholders in the negotiations is still not clear, Timothy Geithner, as a former senior IMF official, had a deep knowledge of and practical experience of international bailout negotiations. He was a senior official in the US Department of the Treasury when it successfully co-ordinated a massive voluntary scheme of commercial bank lending as part of Korea's 1997 IMF programme ${ }^{45}$ and afterwards became a senior IMF official before being appointed as US secretary of the Treasury.

With the EU authorities providing the lion's share of the bailout funds, any intervention by the US to block the deal could have seriously disrupted international relations among the world's major economic powers. It would have implied that the US was attempting to become a decision-maker on European issues. Moreover, it would probably have yielded little as the EU authorities could have walked away from the negotiations and offered funding without IMF involvement. While the Irish case is a clear-cut example of the IMF's staff yielding to their political masters, it is also a case in which the IMF would have found it difficult to act independently without the additional financing provided by the European Financial Stability Fund (EFSF) and European Financial Stability Mechanism (EFSM). At 22.5 billion euro, the IMF's portion of the bailout was already a historically large loan as a percentage of Ireland's undersized IMF quota, yet it was only a fraction of the 85 billion euro package of financial support. The loan was comprised of 12.5 billion provided by Ireland's national pension reserve fund, 5 billion in cash reserves from the Irish, 22.5 billion from the EFSM, 17.5 billion from the EFSF, and bilateral loans from the United Kingdom, Denmark and Sweden to the sum of 5 billion.

\section{Strategic interests}

The role of geopolitics is prominent in the IMF literature but it was not an important consideration for any of the political actors involved in Ireland's EU/IMF bailout. While previous high-profile IMF lending cases in Pakistan, Egypt and Iraq have all had an important geopolitical dimension, the G5 had few security-related reasons for providing Ireland with better terms. A possible exception to this argument is the UK which is perhaps why it was the only dissenting voice during the negotiations. According to economist Morgan Kelly, George Osborne, the chancellor of the Exchequer, was the only one among the G7 finance ministers to speak up for Irish interests. ${ }^{46}$ However, the UK's dissension among the shareholders needs to be put into perspective. Both states share close historical, social and economic ties and maintain a joint interest in the stability of Northern Ireland. Both governments also have a long record of political co-operation enshrined in several

\footnotetext{
${ }^{43}$ James M. Boughton, Tearing down the walls: the International Monetary Fund, 1990-1999 (Washington, DC, 2012): 507.

${ }^{44}$ Michael Brennan, 'US rejects claims it "torpedoed" write-off', Irish Independent, 9 May 2011.

${ }^{45}$ Robert E. Rubin and Jacob Weisberg, In an uncertain world: tough choices from Wall Street to Washington (New York, 2003), 241.

${ }^{46}$ Kelly, 'Ireland's future depends on breaking free from bailout'.
} 
international treaties. For these reasons it should have been expected that the UK would adopt a more critical tone than other shareholders. Ultimately, however, the UK did not move to block the programme until better terms could be agreed, as it had done during Iceland's financial crisis.

\section{The negotiators}

The IMF negotiators were forced to go against good practice and agree to a programme that clearly had no chance of putting Ireland on a sustainable debt path without further external support, thereby removing a central pillar of any international rescue. On the one hand, this could be taken as evidence of the failure of the IMF to live up to its reputation as a technocracy. On the other hand, it could be viewed as a necessary compromise within the given political constraints imposed on the architects of Ireland's programme. There is a reasonable argument that it was the best deal on offer and the only way to 'buy time' in anticipation of further European support. Nevertheless, adherents of the public choice view of international organisations would argue that as a self-interested bureaucracy the IMF holds incentives to yield to the shareholders in difficult cases like Ireland's, even at the expense of a sustainable programme. If it were to refuse to co-operate, it would risk being forced to sit on the sidelines as the EU proceeded with a unilateral bailout. In other words, if the IMF were to refuse to co-operate with its political masters, it would be relegated to the status of an international institution of little importance. Overall, the Irish and European sovereign debt crisis has provoked serious debate and disagreement among the staff. Uncharacteristically for the IMF, this has even leaked into the public domain, as one economist, in their resignation letter, voiced their shame at the institution's failure to address its 'analytical risk aversion, bilateral priority, and European bias', which had contributed to a failure to deal with the global financial crisis and the European sovereign debt crisis. ${ }^{47}$

\section{Domestic politics}

Arguments from the IMF literature that focus on importance of domestic politics during negotiations are not satisfactory when applied to Ireland's bailout. There is little evidence that the G5, EU or IMF's position in the negotiations was affected by Irish politics. Unsurprisingly, most politicians were not aware of the negotiations, which were a closely guarded secret because of their potential to disrupt financial markets. But furthermore in the Irish case, even senior members of government were not briefed. This led to a series of embarrassing communication blunders that were amateurish by the standards of rich democracy, as senior cabinet ministers strongly denied the existence of negotiations just days before the financial package was announced. At the same time, the Department of Finance attempted to delay the decision to accept financial support in order to negotiate better terms. Their delaying tactics were overtaken by external events at the G7 and Eurogroup level. Essentially, their miscalculation was a belief that the government could dictate the pace of negotiations because it still possessed enough cash reserves to continue for several months without external support. This view assumed that outside parties affected by the crisis would not take swift action to prevent it from spilling over into a general run on the European banking system. After the bailout negotiations were made public by Honohan, Ireland's coalition government immediately began to fracture. Fianna Fáil's junior coalition partner, the Green Party, indicated that it would pull out of government after the December budget

\footnotetext{
${ }^{47}$ Peter Doyle, European Department of the International Monetary Fund, Letter to Mr Shaalan, Dean of the IMF Executive Board, 18 June 2012.
} 
and EU/IMF funding programme have been secured. ${ }^{48}$ There is little evidence that this political realignment or the remarkable general election that the bailout precipitated in 2011 had an impact on the major terms of Ireland's programme, namely the pace of fiscal adjustment and the issue of debt restructuring.

\section{CONCLUSIONS}

Ireland's financial crisis may have been largely home-grown but it threatened the stability of the global financial system and the survival of the euro currency. Many of the world's most powerful states had a strong interest in containing the crisis and it was the first item on the G20's agenda in Seoul. While the programme of financial support is sometimes portrayed as a compromise among a group of responsible technocrats, the negotiations were shaped by the political interests of a group of powerful states. This explains why a more comprehensive debt restructuring was not achieved during the negotiations: the IMF's negotiators were unable to act contrary to the interests of Germany, France, the ECB/EC and the other large G7 shareholders. The literature on IMF decision-making demonstrated that these kind of political pressures are a common feature of other international bailouts. Responsible technocrats are ultimately subject to political constraints when negotiating under pressure. There is less convincing evidence to support some of the other arguments from the literature, namely, those that focus on the role of negotiators, domestic politics in the recipient, and the strategic interests of the shareholders.

As the European sovereign debt crisis unfolds, hopefully some of the constraints will loosen and Ireland's unmanageable debt burden can be addressed. Regardless of whether the current programme restores Ireland's credibility in the eyes of the international markets, it is a stern test for Ireland's political system. Few modern democracies have had to undertake such a large fiscal retrenchment in recent decades and it remains an open question whether any economy can withstand what is potentially a lethal dosage of fiscal retrenchment. ${ }^{49}$

\footnotetext{
${ }^{48}$ In cases of government collapse, the IMF often seeks assurance from opposition political parties that they will support the terms of the programme.

${ }^{49}$ The IMF's database on action-based fiscal consolidation shows that, among the advanced economies, only Italy's cutbacks in the 1990s were of a similar magnitude to Ireland's.
} 